\title{
Oral Passive Immunization of Carp Cyprinus carpio with Anti-CyHV-3 Chicken Egg Yolk Immunoglobulin (IgY)
}

\author{
Zhenxing $\mathrm{Liu}^{1,2}$, Hao $\mathrm{Ke}^{2 *}$, Yanping $\mathrm{Ma}^{2}$, Le $\mathrm{Hao}^{2}$, Guoqing Feng ${ }^{2}$, Jiangyao $\mathrm{Ma}^{2}$, \\ Zhiling Liang ${ }^{2}$ and Yugu $\mathrm{Li}^{1 *}$ \\ ${ }^{1}$ College of Veterinary Medicine, South China Agricultural University, Guangzhou 510642, China \\ ${ }^{2}$ Institute of Animal Heath, Guangdong Academy of Agricultural Sciences,
} Guangzhou 510640, China

(Received November 22, 2013)

\begin{abstract}
Cyprinid herpesvirus 3 (CyHV-3), also called as koi herpesvirus, has spread all over the world since its emergence in the late 1990s. CyHV-3 causes a fatal disease, which leads to a mortality rate of more than $80 \%$ in common and ornamental (koi) carp Cyprinus carpio. The novel anti-CyHV-3 strategies are urgently needed. In this report, CyHV-3 particles were concentrated and then used for the immunization of hens in order to obtain the anti-CyHV-3 egg yolk immunoglobulin (IgY). The proportion of anti-CyHV-3 IgY to total IgY in water-soluble fraction of egg york increased from $0.014 \%$ to $23.9 \%$ after three times of immunization. The anti-CyHV-3 effects of IgY were then examined by in vivo and in vitro assays. The results suggested that the anti-CyHV-3 serum of hens and the purified anti-CyHV-3 IgY from eggs could prevent common carp brain (CCB) cells from infection. After oral passive immunization with IgY, the mortality of carp significantly decreased from $85 \%$ to $50 \%(P<0.05)$ when the fish were challenged with CyHV-3 at a dose of $40 \mathrm{TCID}_{50} / \mathrm{fish}$. These results will possibly pave the way for the prevention of CyHV-3 infection.
\end{abstract}

Key words: Cyprinid herpesvirus 3, KHV, carp, yolk immunoglobulin, IgY, oral passive immunization

Cyprinid herpesvirus 3 (CyHV-3), also called as koi herpesvirus (KHV), represents a member of genus Cyprinivirus belonging to the family alloherpesviridae. Since its emergence in the late 1990s, CyHV-3 has spread all over the world, leading to massive economic losses (Michel et al., 2010). Due to its fatal infection, the mortality of common and ornamental (koi) carp Cyprinus carpio infected with CyHV-3 is usually over $80 \%$ under experimental and natural infection conditions (Bergmann et al., 2010). Vaccination is generally considered to be the most effective method to prevent the virus infection. So far, the attenuated and inactivated vaccines have been developed to control CyHV-3 (Perelberg et al., 2008; Yasumoto et al., 2006). However, the attenuated vaccine seems to retain residual virulence. Moreover, it is hard to distinguish the immunized fish from those infected with wild-type CyHV-3 because of the seropositivity. It might bring a lot of problems in the international trade of such kind of immunized fish. Thus, it is an urgent need to develop the novel and effective strategies against CyHV-3 infection.

\footnotetext{
* Corresponding authors

Hao Ke. E-mail: keha@tom.com

Yugu Li. E-mail: liyugu@scau.edu.cn
}

The intestine and periodontal pharyngeal mucosa of the digestive tract have been recently confirmed as portals of entry for CyHV-3, in addition to the skin (Monaghan et al., 2014; Fournier et al., 2012). Moreover, enteritis is one of the clinical signs resulted from the infection (Hedrick et al., 2000), and replication of CyHV3 is detected in intestine of infected carp (Dishon et al., 2005; Syakuri et al., 2013). These results suggest that alimentary tract might be a potential therapeutic target during CyHV-3 infection. Chicken egg yolk immunoglobulin ( $\lg Y$ ) referring to the antibodies transferred from serum to the egg yolk, has been used for the prevention of viral or bacterial pathogens in the digestive tract by oral passive immunization (Rahman et al., 2013). Oral administration of IgY is especially suitable for fish and exhibits favorable effects (Arasteh et al., 2004; Gutierrez et al., 1993; Lee and Mine, 2000). In this study, we have prepared the anti-CyHV-3 IgY and examined its role in the prevention of CyHV-3 infection.

\section{Materials and Methods}

Fish, cells and virus

Carp of 10-25 g were bought from Pearl River Fisheries Research Institute, Chinese Academy of Fishery 
Sciences and raised in aquaria filled with $40 \mathrm{~L}$ water. The water temperature was kept at $25^{\circ} \mathrm{C}$ with a $1 / 3$ water change once a day. Common Carp Brain (CCB) cells were cultivated at $25^{\circ} \mathrm{C}$ in Minimum Essential Medium (Invitrogen corp.) containing 10\% fetal bovine serum (Invitrogen corp.). The CyHV-3 ZS38 strain was isolated from a diseased carp in a fish farm located in south China in 2009.

\section{Purification of CyHV-3 and immunization of hens}

The CyHV-3 ZS38 strain was inoculated to CCB cells. The cultures were harvested until the cytopathic effect (CPE) was observed in $90 \%$ of the cells and its titer was determined by $\operatorname{TCID}_{50}$ assay (Trkola et al., 1995).

The cell culture was applied to the clarification of CyHV-3 according to the method developed previously (Yasumoto et al., 2006) with slight modifications. Briefly, after 3 freeze-thaw cycles, the debris of CCB cells in the cultures were removed by centrifugation at $3,000 \times g$ at $4^{\circ} \mathrm{C}$ for $20 \mathrm{~min}$. The supernatant was collected for the clarification of virus by ultracentrifugation at $45,000 \times g$ at $4^{\circ} \mathrm{C}$ for $60 \mathrm{~min}$. The obtained CyHV-3 particles were suspended in the TEN $(0.05 \mathrm{M}$ Tris- $\mathrm{HCl}$, $0.15 \mathrm{M} \mathrm{NaCl}, 0.001 \mathrm{~m}$ EDTA, pH7.2). The concentration of total protein was determined by BCA Protein Assay Kit (Tiangen Biotech Co., Ltd.) and then stored at $-80^{\circ} \mathrm{C}$ until used. The isolated CyHV-3 was negatively stained and examined by transmission electron microscope (Hitachi, Ltd.).

Eighteen laying hens were divided into 3 groups $(n=6)$. Two groups of them were immunized with concentrated CyHV-3 emulsified in Freund' adjuvant (Sigma-Aldrich, Inc.) and ISA70VG adjuvant (Seppic), respectively, which named as $\mathrm{F}$ group and I group. Another group, C group, was injected with PBS without adjuvant and served as the control. A detailed immunization scheme was showed in Table 1.

\section{Serum and $\lg Y$}

The serum and $\lg Y$ were collected after 10 days of each immunization and then at 10-day intervals after the third injection. The blood was taken with syringes and clotted at $37^{\circ} \mathrm{C}$ for $2 \mathrm{~h}$. The serum was then separated by centrifugation at $3,000 \times g$ at $4^{\circ} \mathrm{C}$ for $20 \mathrm{~min}$. The IgY was obtained in WSF (water-soluble fraction) of the egg yolk according to the method described previ- ously (Lu et al., 2009). The serum and egg yolk IgY were used to detect the antibody response.

\section{Anti-virus ELISA and egg collection}

The serum antibody and egg yolk IgY were detected by indirect ELISA. Briefly, the wells of a 96well ELISA plate were coated by $100 \mu \mathrm{L} /$ well of concentrated CyHV-3 antigen $(1 \mu \mathrm{g} / \mathrm{mL})$ in carbonate-bicarbonate buffer ( $\mathrm{pH} \mathrm{9.6)}$ at $4^{\circ} \mathrm{C}$ overnight. The plate was washed 3 times with PBS ( $\mathrm{pH} 7.4,0.01 \mathrm{~m})$ containing $0.05 \%(v / v)$ Tween 20 (PBST) and then blocked with $200 \mu \mathrm{L} /$ well of PBS containing $1 \%(\mathrm{w} / \mathrm{v}) \mathrm{BSA}$ at $37^{\circ} \mathrm{C}$ for $2 \mathrm{~h}$. After rinsing with PBST, $100 \mu \mathrm{L}$ of diluted serum (1:6400) or diluted IgY (1:3200) were added into each well in duplicate. The plate was incubated at $37^{\circ} \mathrm{C}$ for $2 \mathrm{~h}$. After washing with PBST, $100 \mu \mathrm{L} /$ well of diluted (1:10000) rabbit anti-chicken (IgY)-IgG conjugated with HRP (Sigma-Aldrich, Inc.) was added and the plate was placed at $37^{\circ} \mathrm{C}$ for $1 \mathrm{~h}$. The plate was washed again and $100 \mu \mathrm{L}$ of TMB substrate solution was added into each well. The plate was incubated at $37^{\circ} \mathrm{C}$ for $10 \mathrm{~min}$ and then the reaction was stopped by $50 \mu \mathrm{L} /$ well of $2 \mathrm{M} \mathrm{H}_{2} \mathrm{SO}_{4}$. Absorbance was determined at $450 \mathrm{~nm}$ with a plate reader (Thermo Fisher Scientific Inc.).

When the levels of anti-CyHV-3 reached the peak value (10 days after the third immunization) the eggs from $F$ and I groups were collected, separately. In essence, the specific anti-CyHV-3 IgY in the eggs was not different between the $F$ group and I group. The eggs of $\mathrm{F}$ group were used for the next assay.

\section{Purification of $\lg Y$}

Six eggs were selected randomly from the collection of $F$ group eggs, the yolk was isolated and used as the pooled sample for the purification assay. Five methods were used to purify IgY from the same egg yolk sample. The ethanol precipitation, chloroform extraction, PEG precipitation, $\mathrm{Na}_{2} \mathrm{SO}_{4}$ precipitation and $\left(\mathrm{NH}_{4}\right)_{2} \mathrm{SO}_{4}$ precipitation were performed according to the procedures described previously (Schade et al., 2001; Lu et al., 2009). The purity of the extracted IgY was detected by sodium dodecyl sulfate-polyacrylamide gel electrophoresis (SDS-PAGE) and its anti-CyHV-3 titer was determined by ELISA as described in anti-virus ELISA.

Table 1. Immunization scheme

\begin{tabular}{ccccc}
\hline immunization & days after first & antigen dosage & \multicolumn{2}{c}{ adjuvant } \\
\cline { 4 - 5 } order & immunization & $(\mu \mathrm{g})$ & F group & I group \\
\hline $1^{\text {st }}$ & - & 100 & CFA & ISA70VG \\
$2^{\text {nd }}$ & 14 & 200 & IFA & ISA70VG \\
$3^{\text {rd }}$ & 28 & 300 & IFA & ISA70VG \\
\hline
\end{tabular}

CFA: complete Freund's adjuvant; IFA: incomplete Freund's adjuvant. 


\section{Determination of $\lg Y$ concentration}

The concentration of total IgY was determined by the capture ELISA developed previously (Lee et al., 2002). The concentration of specific anti-CyHV-3 IgY was measured by indirect ELISA. A 96-well ELISA plate was coated with $100 \mu \mathrm{L}$ of $20 \mu \mathrm{g} / \mathrm{mL}$ concentrated CyHV-3. After blocking, two-fold serial dilutions of WSF and $\operatorname{Ig} Y$ (purified by $\mathrm{Na}_{2} \mathrm{SO}_{4}$ precipitation) were added in duplicate. Rabbit anti-chicken IgG conjugated with HRP (Sigma-Aldrich, Inc.) was added subsequently. Other ELISA procedures were undertaken according to ELISA described in anti-virus ELISA.

\section{Neutralization assay (in vitro test)}

The neutralization activities of specific $\lg Y$ and serum were calculated in terms of $50 \%$ neutralization dose $\left(\mathrm{ND}_{50}\right)$. CCB cells were inoculated as described above. Two eggs were randomly selected from the collection of $\mathrm{F}$ group eggs, then the $\operatorname{Ig} Y$ was purified by $\mathrm{Na}_{2} \mathrm{SO}_{4}$ precipitation as mentioned above. The antiCyHV-3 serum was from $F$ group post the third immunization. The non-specific IgY and negative serum from $C$ group were also prepared in the same way. In addition, the anti-CyHV-3 titer of IgY and serum was determined as mentioned above. The IgY and serum were inactivated at $56^{\circ} \mathrm{C}$ for $1 \mathrm{~h}$ and then serially diluted in MEM (1:2-1:256). The CyHV-3 was adjusted to $200 \mathrm{TCID}_{50} / \mathrm{mL}$ in MEM and mixed with an equal volume of above dilutions. The mixture was incubated at $25^{\circ} \mathrm{C}$ for $1 \mathrm{~h}$ and then added into 8 replicate wells of CCB cells plate (200 $\mu \mathrm{L} /$ well) replacing the original MEM. The plate was kept at $25^{\circ} \mathrm{C}$ for 14 days. Based on the observation of CPE, $\mathrm{ND}_{50}$ was calculated by the formula of Reed and Munch (1938).

\section{Uptake of $\lg Y$}

The IgY was purified from $\mathrm{F}$ group eggs by $\mathrm{Na}_{2} \mathrm{SO}_{4}$ precipitation as mentioned above, and then adjusted to $8 \mathrm{mg} / \mathrm{mL}$ (PBS, $\mathrm{pH}$ 7.2). Twenty four carp were used to determine the uptake of IgY. Three unfed fish were severed as the control ( 0 day). The other 21 carp were intragastrically administrated with the purified $\lg Y$ at $0.04 \%$ body weight. In the following 7 days, 3 fish were euthanized every day and their serum, intestine, liver were collected and pooled, respectively. The serum was diluted in five times volume of PBS. The intestine was dissected and flushed thoroughly with PBS to remove intestinal contents, then the intestine and liver were homogenized in PBS (20\%, w/v) and centrifuged at $3,000 \times g$ at $4^{\circ} \mathrm{C}$ for $20 \mathrm{~min}$ to obtain the supernatant. The prepared samples were used to determine the concentration of total IgY by the capture ELISA described above.

\section{Preparation of feed}

The IgY was purified from $\mathrm{F}$ group or $\mathrm{C}$ group through the $\mathrm{Na}_{2} \mathrm{SO}_{4}$ precipitation, and the concentration of total IgY was determined as mentioned above. Then the carp feed containing specific IgY (from $F$ group) or non-specific IgY (from C group) was prepared according to the method described by Arasteh et al. (2004). The IgY was calculated in terms of total IgY and added into the commercial pellets at the weight ratio of $0.05 \%$. Briefly, IgY was sprayed onto commercial pellets (Uni-president Co. Ltd.) to obtain the pellets containing specific or non-specific IgY. The pellets were dried and stored at $4^{\circ} \mathrm{C}$ until used. One gram samples of each kind of pellets was immersed in $\mathrm{ddH}_{2} \mathrm{O}$ at $4^{\circ} \mathrm{C}$ for $4 \mathrm{~h}$ and then centrifuged at $10,000 \times g$ at $4^{\circ} \mathrm{C}$ for $20 \mathrm{~min}$. The supernatant was collected to determine the anti-CyHV-3 IgY titer by ELISA described in anti-virus ELISA.

\section{Challenge test (in vivo test)}

Eighty carp were divided into 4 groups $(n=20)$ and then were fed above-mentioned pellets for 10 successive days as described below. The fish were fed with the prepared pellets twice daily, at 9:00-10:00 am and 16:00-17:00 pm at $2 \%$ body weight throughout the trial. Fish of group 1 and group 3 were orally administered with specific IgY pellets, group 2 and group 4 were fed with non-specific IgY pellets. Carp of group 1, 2 and group 3, 4 were then infected by inoculating CyHV-3 onto the gills (El-Din, 2011) at a dose of 80 and 40 $\mathrm{TCID}_{50}$ of CyHV-3, respectively. The mortality of challenged carp was observed daily. The protection effect was evaluated as the relative percent survival: RPS = (1 - passively vaccinated group mortality/control group mortality) $\times 100 \%$ (Yasumoto et al., 2006).

\section{Clinical signs and pathological examination}

Six dead carp from the middle of challenge test (7-14 days post infection (d.p.i.)) were dissected for parasitological and microbiological examinations. Todd-Hewitt broth (THB) and nutrient agar (NA) were used to isolate bacteria from the gills, brain, liver and kidney. The isolated bacteria were identified by the PCR amplification and sequence of 16S rRNA gene (Weisburg et al., 1991). The total DNA from the brain tissue of the dead carp was used as the template to amplify the Sphl-5 fragment of CyHV-3 (Gray et al., 2002). The PCR products were sequenced. The sera of 3 survived carp were collected at the 28 d.p.i.. Anti-CyHV-3 IgM titer was assessed by the ELISA developed previously (St-Hilaire et al., 2009).

\section{Statistical methods}

SPSS13 was used to perform the statistical analysis. The data of IgY concentration was analyzed using the one-way ANOVA followed by the Duncan multi-comparison of means test. The mortalities observed in the challenge test were analyzed using the 
Fisher's exact test. The significant level was considered as $P=0.05$.

\section{Results}

Production of the anti-CyHV-3 antibodies

The titer of virus stock reached $10^{4.2} \mathrm{TCID}_{50} / \mathrm{mL}$

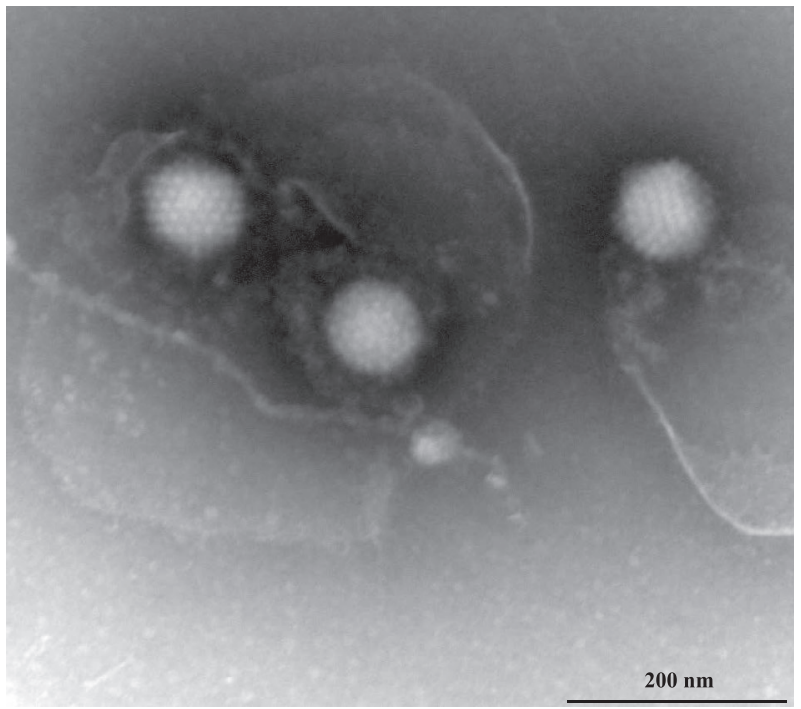

Fig. 1. Transmission electron microscopy. The concentrated CyHV-3 was detected by transmission electron microscopy (negative staining) and relatively intact virus was obtained (Fig. 1). The antibodies production of $F$ group (immunized with Freund' adjuvant) was slightly faster than that of I group (immunized with ISA70VG adjuvant), and the peak of antibody titer occurred earlier in serum than in egg yolk (Fig. 2). The antibody titer in serum and egg yolk from $\mathrm{F}$ group and I group finally rose to the similar level.

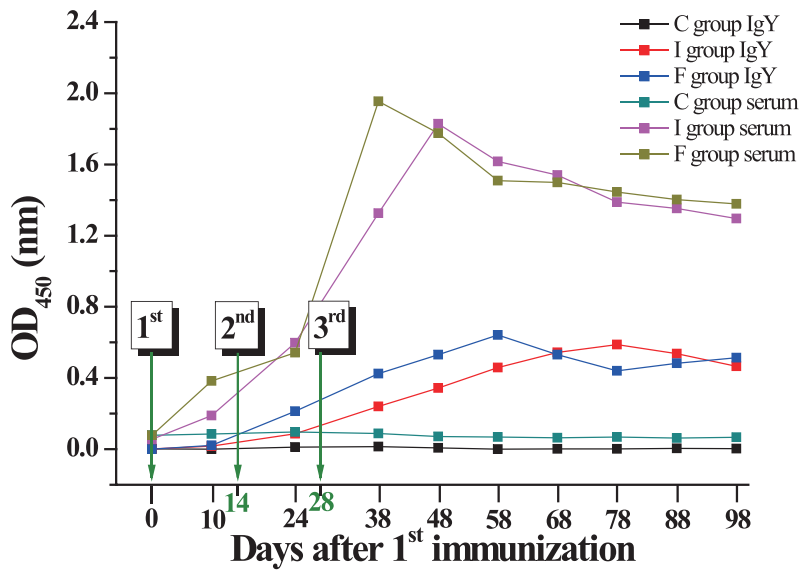

Fig. 2. Production of the anti-CyHV-3 antibodies. Titer of serum and IgY in WSF against CyHV-3 were measured by ELISA. F group: CyHV-3 with Freund' adjuvant, I group: CyHV-3 with ISA70VG adjuvant, C group: PBS without adjuvant. Arrows indicate the immunization time points. Values represent the means of duplicate wells.

Table 2. The anti-CyHV-3 titer of the IgY purified by different methods

\begin{tabular}{cccccc}
\hline $\begin{array}{c}\text { Purification } \\
\text { methods }\end{array}$ & $\begin{array}{c}\text { chloroform } \\
\text { extraction }\end{array}$ & $\begin{array}{c}\text { PEG } \\
\text { precipitation }\end{array}$ & $\begin{array}{c}\text { ethanol } \\
\text { precipitation }\end{array}$ & $\begin{array}{c}\mathrm{Na}_{2} \mathrm{SO}_{4} \\
\text { precipitation }\end{array}$ & $\begin{array}{c}\left(\mathrm{NH}_{4}\right)_{2} \mathrm{SO}_{4} \\
\text { precipitation }\end{array}$ \\
\hline Antibody titer & $>1: 25600$ & $>1: 12800$ & $>1: 6400$ & $>1: 25600$ & $>1: 25600$ \\
\hline
\end{tabular}

Values represent the means of duplicate wells.

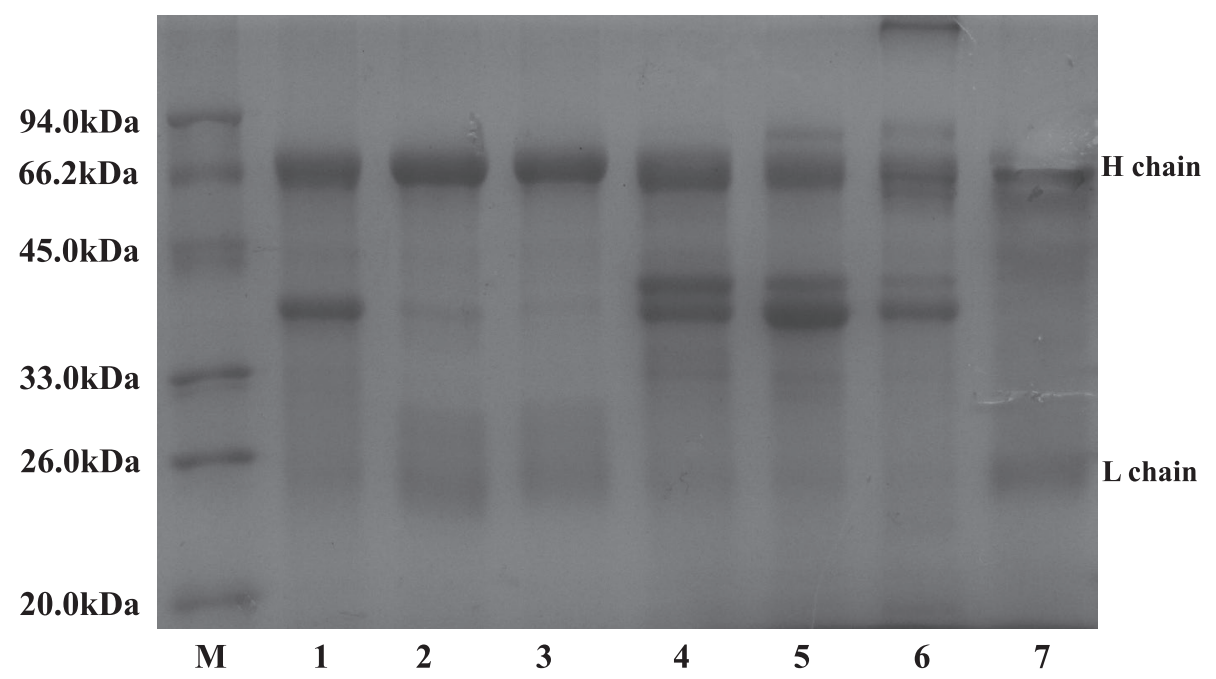

Fig. 3. SDS-PAGE of IgY purified by different methods. The IgY was extracted by $\left(\mathrm{NH}_{4}\right)_{2} \mathrm{SO}_{4}$ precipitation (lane 1), $\mathrm{Na}_{2} \mathrm{SO}_{4}$ precipitation (lane 2), PEG precipitation (lane 3), ethanol precipitation (lane 4), chloroform extraction (lane 5), WSF (lane 6). The arrows indicate the heavy chain and light chain of the standard IgY (Sigma). Protein molecular weight markers are used to calculate sample molecular weights (lane M). 


\section{Purification of egg yolk $\lg Y$}

IgY purified by chloroform extraction, $\mathrm{Na}_{2} \mathrm{SO}_{4}$ precipitation and $\left(\mathrm{NH}_{4}\right)_{2} \mathrm{SO}_{4}$ precipitation showed higher antibody titer (Table 2). SDS-PAGE indicated that comparatively pure IgY was purified by the $\left(\mathrm{NH}_{4}\right)_{2} \mathrm{SO}_{4}$ or PEG precipitation (Fig. 3). In this study, $\mathrm{Na}_{2} \mathrm{SO}_{4}$ precipitation was a preferable method. Therefore, IgY extracted by $\mathrm{Na}_{2} \mathrm{SO}_{4}$ precipitation was used for the in vitro and in vivo anti-CyHV-3 tests.

\section{Concentration of egg yolk $\lg Y$}

The concentration of total IgY and specific antiCyHV-3 IgY was measured, respectively. The result showed that the concentration of total $\lg Y$ from $\mathrm{F}$ or $\mathrm{C}$ group eggs was not significantly different $(P>0.05)$ post the immunization, but the concentration of specific IgY (in the $\mathrm{F}$ group eggs) increased remarkably $(P<$ 0.05 ) (Table 3 ) compared to that in the $C$ group eggs. These data indicated that the immunization of CyHV-3 did not change the total IgY level, but that of specific anti-CyHV-3 IgY. The increased tendency of specific anti-CyHV-3 IgY in F and I group was also observed in Fig.2.

\section{Neutralization activities of $\lg Y$ in vitro}

The neutralization assay revealed that specific $\lg Y$ or serum could prevent the CCB cells from being infected with CyHV-3. CPE was observed in all control wells (added non-specific IgY and corresponding negative serum) at 5 d.p.i., at the same time, no CPE appeared in the wells added specific IgY or serum. It indicated that the specific antibody could delay the course of CyHV-3 infection. Finally (14 d.p.i.), their values of $\mathrm{ND}_{50}$ were $1 / 18.77$ and $1 / 3.34$, respectively. This result was associated with the difference of antiCyHV-3 titer between serum (> 1:102400) and IgY (> 1:12800).

\section{Uptake of $\lg Y$}

Three days after the intragastric administration, the relatively constant total concentration of $\lg Y$ was detected in the liver, intestine and serum, respectively (Fig. 4). The IgY could be transported into serum, suggesting that $\lg Y$ could be distributed to other tissue by the circulatory system.

Table 3. Concentration of egg yolk $\lg Y$

\begin{tabular}{|c|c|c|c|}
\hline & WSF (C group) & WSF (F group) & $\begin{array}{c}\lg \mathrm{(F} \text { group) } \\
\text { purified by } \mathrm{Na}_{2} \mathrm{SO}_{4} \\
\text { precipitation }\end{array}$ \\
\hline total $\lg Y(\mathrm{mg} / \mathrm{mL})$ & $1.21 \pm 0.11$ & $1.19 \pm 0.13$ & $1.89 \pm 0.35$ \\
\hline specific $\lg Y(\mathrm{mg} / \mathrm{mL})$ & $0.00016 \pm 0.00059$ & $0.28 \pm 0.016^{*}$ & $0.44 \pm 0.041$ \\
\hline $\begin{array}{l}\text { proportion of specific } \lg Y \\
\text { in total } \lg Y(\%)\end{array}$ & 0.014 & 23.9 & 23.3 \\
\hline
\end{tabular}

Values of $\lg Y$ concentration are the means of triple samples \pm SD. Asterisk denotes significant differences $(P<0.05)$ of specific IgY concentration in WSF between $\mathrm{C}$ group and $\mathrm{F}$ group.

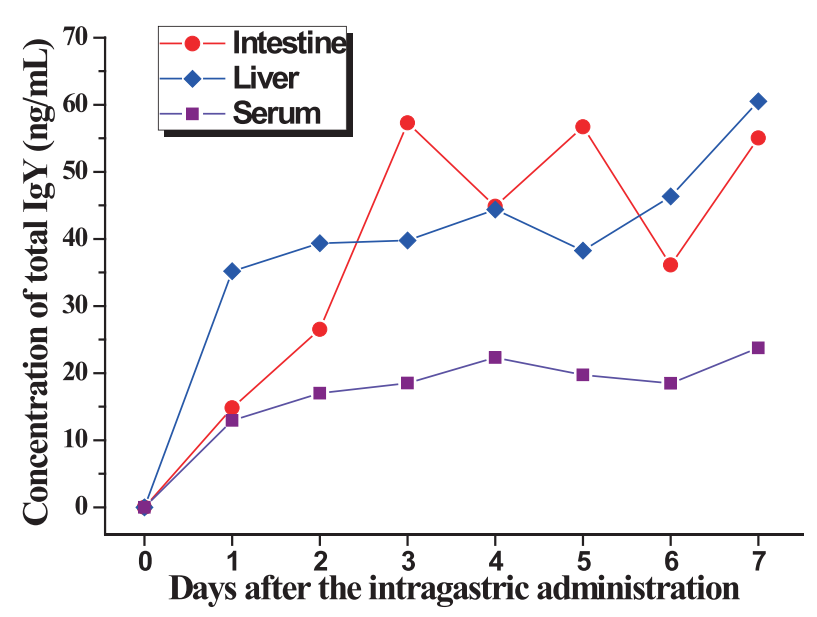

Fig. 4. Detection of total concentration of $\lg Y$ absorbed in the carp serum, liver and intestine tissue of the fish intragastrically administrated with the specific IgY pellets. Values represent the means of duplicate wells.

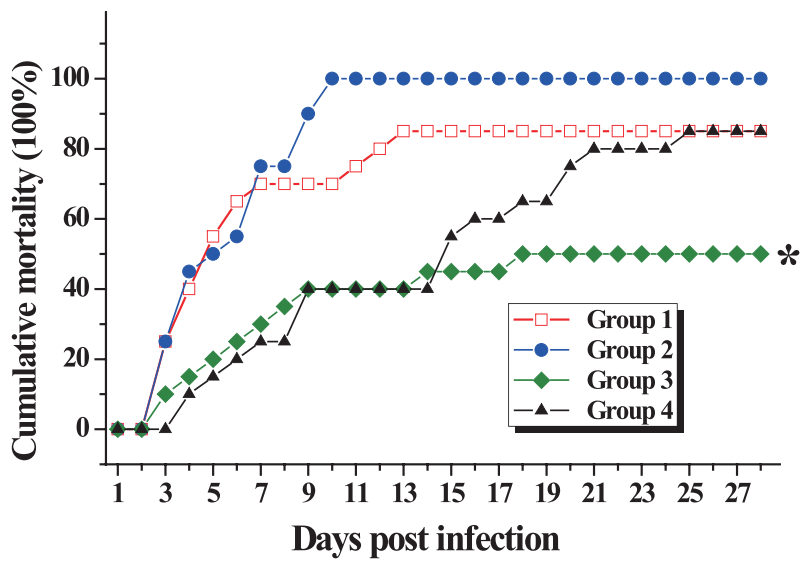

Fig. 5. In vivo protection induced by $\lg \mathrm{Y}$ administration. Carp were divided into 4 groups ( $n=20$ fish/group) and challenged with CyHV-3 (group 1 and 2: 80 $\mathrm{TCID}_{50} /$ fish, group 3 and 4: $40 \mathrm{TCID}_{50} /$ fish) after feeding with IgY pellets (group 1 and $3: 0.05 \%(w / w)$ specific IgY, group 2 and 4: $0.05 \%$ (w/w) non-specific $\lg Y$ ) for 10 consecutive days. 


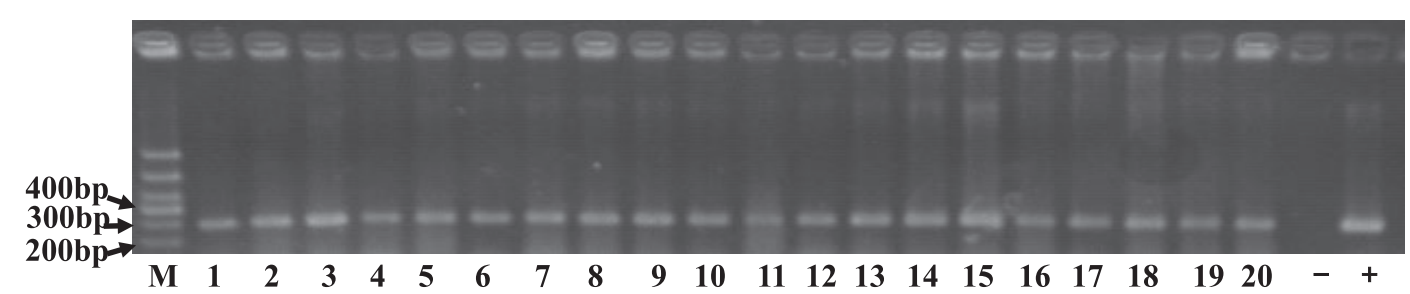

Fig. 6. Detection of CyHV-3 DNA by PCR. The DNA templates were extracted from the brains of the dead carp from the in vivo test. One third of the dead carp were randomly examined. M: DNA marker (DL1000); lane 1-5: partial dead carp from group 1, lane 6-10: partial dead carp from group 2, lane 11-15: partial dead carp from group 3, lane 16-20: partial dead carp from group 4; +: positive control; -: negative control.

\section{Anti-CyHV-3 effect of specific lgY in carp}

The mortality was associated with the infectious dose of CyHV-3. The infection with $80 \mathrm{TCID}_{50}$ of the virus caused $100 \%$ mortality at 10 d.p.i. and the lower mortality $(85 \%)$ was induced by challenge with 40 $\mathrm{TCID}_{50}$ of the virus in the control group fed with non-specific IgY pellets. Passive immunization of carp with specific IgY provided resistance to the CyHV-3 infection. The protective effect was affected by the infectious dose: when fish were challenged with a higher dose of CyHV-3 (80 TCID $50 /$ fish), the mortality decreased by $30 \%(P<0.05)$ at 10 d.p.i.. But the final cumulative mortality (28 d.p.i.) was, however, not significantly different $(P>0.05)$, the survival rate maintained $15 \%$ (28 d.p.i.), oral administration of specific IgY could delay the death course of infected fish. Under the condition of a lower infectious dose (40 TCID 50 fish), the mortality reduced from $85 \%$ to $50 \%(P<0.05)$ at 28 d.p.i. (Fig. 5$)$ and RPS was $41.18 \%$.

\section{Pathogeny and anti-CyHV-3 IgM}

The typical clinical signs including skin lesion, gill necrosis, kidney enlargement et al. were observed in almost all the dead carp. No parasite was found under the microscope and only Aeromonas veronii was isolated from the gills of all the 6 diagnosed carp, but nearly no bacteria were cultured from the brain, liver or kidney. On the contrary, CyHV-3 was detected in all dozens of the brain samples (Fig. 6), suggesting that CyHV-3 was the main cause of the acute death. Some carp survived from the challenge, and three of them were chosen for the examination of IgM against CyHV-3. The result of ELISA indicated that the 3 survival fish were seropositive (Table 4).

Table 4. Anti-CyHV-3 serum IgM titer of the survival carp

\begin{tabular}{ccc}
\hline carp & OD450 (1:400) & OD450 (1:800) \\
\hline $1 \#$ & 0.521 & 0.271 \\
$2 \#$ & 0.439 & 0.268 \\
$3 \#$ & 0.514 & 0.288 \\
uninfected carp & 0.041 & 0.029 \\
\hline
\end{tabular}

Values represent the means of duplicate wells.

\section{Discussion}

Due to the severely financial losses in the common carp and koi carp culture industries worldwide caused by CyHV-3, how to prevent the damage of CyHV-3 becomes a global issue. No effective methods have been applied for the prevention of CyHV-3 except two types of vaccines (Perelberg et al., 2008; Yasumoto et al., 2006). The attenuated vaccine offers ideal protection against CyHV-3, however, the mortality of the immunized fish could reach $30 \%$ when the fish are kept at permissive temperature $\left(24^{\circ} \mathrm{C}\right)$. Although the authors assume that a general inferior immune response or CyHV-3 non-related pathogens should be responsible for the mortality, the residual virulence could not be excluded. In addition, there is a risk of reverse to violence for the attenuated virus. The inactivated vaccine is safer and RPS ranging from $65.0 \%$ to $74.3 \%$ has been obtained. The protection induced by oral passive immunization with specific IgY is inferior (RPS was $41.18 \%$ ). But the IgY have an advantage that the administration of IgY provides protection by the consumption of little time (10 days in our challenge test). In vaccine researches, a period of 3 to 6 weeks after the initial immunization is generally required for the antibody titer rising to a high level (Ronen et al., 2003; Adkison et al., 2005), in other words, there is a possible dangerous period of several weeks before the vaccine plays the protective role. In fact, the common or koi carp are usually challenged at 22 days post vaccination (d.p.v.) or 27 d.p.v. (Perelberg et al., 2008; Yasumoto et al., 2006). By contrast, the oral passive immunization just needs several days. Furthermore, the IgY incorporated into the pellets exhibits excellent stability, the activity does not decrease after storage for 2 months at $4^{\circ} \mathrm{C}$ (data not shown).

The portals of entry for CyHV-3 are important and ideal drug targets, which largely decide the methods of drug administration. The skin, pharyngeal mucosa, gills and intestine have been indicated as the major portals of entry (Costes et al., 2009; Fournier et al., 2012; Monaghan et al., 2014). They act under different epidemiological conditions: CyHV-3 can enter carp either by skin contact or by digestive tract after ingestion of infec- 
tious materials, for example the virus-contaminated freshwater mussels (Kielpinski et al., 2010). There is a hypothesis that the CyHV-3 invades intestinal epithelial cells then spreads to the other tissues via the blood causing a systemic infection (Lee et al., 2012). The first line of defense against CyHV-3 should be located in digestive tract of fish. In our study, the virus has been inoculated onto gills which are connected with the oropharyngeal cavity adjoining intestine. They are the targets of virus entry and replication. On the other hand, the $\lg Y$ is mainly enriched in the alimentary system including intestine and liver after the oral immunization. So we assume that the IgY plays a preventive role through the neutralization effect in the alimentary system.

Anti-CyHV-3 IgM has been detected in the serum of survival fish, which might result from the uptakes of degenerated CyHV-3 neutralized by IgY or the invasion of virus. Although the challenge dosage is low (40 or $80 \mathrm{TCID}_{50}$ per fish), the virus will replicate in the infectious carp, then the multiplicated virus can be released into the water. In addition, the virus could be also spread through skin contact. The challenge test indicates an intense outbreak of KHVD considering that the mortality of the control fish is no less than $85 \%$. The antigen of virus might be sufficient to induce antibody production in fish. Moreover, fish intestine could absorb large protein molecules even the intact rabbit IgG (Nakamura et al., 2004). So we speculate that the degenerated fragments or intact virus constitute the source of antigen. In fact, the production of anti-CyHV$3 \mathrm{IgM}$ may be more important for carp to survive from the challenge (Perelberg et al., 2008).

In summary, our study suggests the first report of the passive immunization of carp with anti-CyHV-3 IgY, and the administration of specific $\lg Y$ can reduce the mortality of carp challenged with CyHV-3. These researches supply a possible method to control the infection of CyHV-3.

\section{Acknowledgments}

This study was supported by Natural Science Foundation of Guangdong Province, China (10151064001000020), Science and Technology Planning Project of Guangdong Province, China (2012B020308012). The CCB cells were kindly provided by Dr. Sven M. Bergmann, Federal Research Institute for Animal Health, Germany. The authors do not have any possible conflicts of interest.

\section{References}

Adkison, M. A., O. Gilad and R. P. Hedrick (2005): An enzyme linked immunosorbent assay (ELISA) for detection of antibodies to the koi herpesvirus (KHV) in the serum of koi
Cyprinus carpio. Fish Pathol., 40, 53-62.

Arasteh, N., A. H. Aminirissehei, A. N.Yousif, L. J. Albright and T. D. Durance (2004): Passive immunization of rainbow trout (Oncorhynchus mykiss) with chicken egg yolk immunoglobulins (IgY). Aquaculture, 231, 23-36.

Bergmann, S. M., M. Riechardt, D. Fichtner, P. Lee and J. Kempter (2010): Investigation on the diagnostic sensitivity of molecular tools used for detection of koi herpesvirus. J. Virol. Meth., 163, 229-233.

Costes, B., V. Stalin Raj, B. Michel, G. Fournier, M. Thirion, L. Gillet, J. Mast, F. Lieffrig, M. Bremont and A. Vanderplasschen (2009): The major portal of entry of koi herpesvirus in Cyprinus carpio is the skin. J. Virol., 83, 2819-2830.

Dishon, A., A. Perelberg, J. Bishara-Shieban, M. llouze, M. Davidovich, S. Werker and M. Kotler (2005): Detection of carp interstitial nephritis and gill necrosis virus in fish droppings. Appl. Env. Microbiol., 71, 7285-7291.

El-Din, M. M. M. (2011): Histopathological studies in experimentally infected Koi carp (Cyprinus carpio koi) with Koi Herpesvirus in Japan. World J. Fish Marine Sci., 3, 252-259.

Fournier, G., M. Boutier, V. Stalin Raj, J. Mast, E. Parmentier, P. Vanderwalle, D. Peeters, F. Lieffrig, F. Farnir, L. Gillet and A. Vanderplasschen (2012): Feeding Cyprinus carpio with infectious materials mediates cyprinid herpesvirus 3 entry through infection of pharyngeal periodontal mucosa. Vet. Res., 43:6.

Gray, W. L., L. Mullis, S. E. LaPatra, J. M. Groff and A. Goodwin (2002): Detection of koi herpesvirus DNA in tissues of infected fish. J. Fish Dis., 25, 171-178.

Gutierrez, M. A., T. Miyazaki, H. Hatta and M. Kim (1993): Protective properties of egg yolk IgY containing anti-Edwardsiella tarta antibody against paracolo disease in the Japanese eel, Anguilla japonica Temminck \& Schlegel. J. Fish Dis., 16, 113-122.

Hedrick, R. P., O. Gilad, S. Yun, J. V. Spangenberg, G. D. Marty, R. W. Nordhausen, M. J. Kebus, H. Bercovier and A. Eldar (2000): A herpesvirus associated with mass mortality of juvenile and adult koi, a strain of common carp. J. Aquat. Anim. Health, 12, 44-57.

Kielpinski, M., J. Kempter, R. Panicz, J. Sadowski, H. Schütze, S. Ohlemeyer and S. M. Bergmann (2010): Detection of $\mathrm{KHV}$ in freshwater mussels and crustaceans from ponds with khv history in common carp (Cyprinus carpio). Israeli J. Aquacult., 62, 28-37.

Lee, E. N., H. H. Sunwoo, K. Menninen and J. S. Sim (2002): In vitro studies of chicken egg yolk antibody (IgY) against Salmonella enteritidis and Salmonella typhimurium. Poultry Sci., 81, 632-641.

Lee, N. S., S. H. Jung, J. W. Park and J. W. Do (2012): In situ hybridisation detection of koi herpesvirus in paraffinembedded tissues of Common carp Cyprinus carpio collected in 1998 in Korea. Fish Pathol., 47, 100-103.

Lee, S. B. and Y. Mine (2000): Effect of hen egg yolk immunoglobulin in passive protection of rainbow trout against Yersinia ruckeri. J. Agricult. Food Chem., 48, 110-115.

Lu, Y. N., J. J. Liu, L. J. Jin, X. Y. Li, Y. H. Zhen, H. Y. Xue, Q. Y. Lin and Y. P. Xu (2009): Passive immunization of crayfish (Procambius clarkiaii) with chicken egg yolk immunoglobulin (IgY) against white spot syndrome virus (WSSV). Appl. Biochem. Biotech., 159, 750-758.

Monaghan, S. J., K. D. Thompson, A. Adams, J. Kempter and S. M. Bergmann(2014): Examination of the early infection stages of koi herpesvirus (KHV) in experimentally infected carp, Cyprinus carpio L. using in situ hybridization. J. Fish Dis., doi: 10.1111/jfd.12260.

Michel, B., G. Fournier, F. Lieffrig, B. Costes and A. 
Vanderplasschen (2010): Cyprinid Herpesvirus 3. Emerging Infect. Dis., 16, 1835-1843.

Nakamura, O., Y. Tazumi, T. Muro, Y. Yasuhara and T. Watanabe (2004): Active uptake and transport of protein by the intestinal epithelial cells in embryo of viviparous fish, Neoditrema ransonneti (Perciformes: Embiotocidae). J. Exp. Zool., Part A: Comp. Exp. Biol., 301, 38-48.

Perelberg, A., M. Ilouze, M. Kotler and M. Steinitz (2008): Antibody response and resistance of Cyprinus carpio immunized with cyprinid herpes virus 3 (CyHV-3). Vaccine, 26, 3750-3756.

Rahman, S., S. Van Nguyen, F. C. Jr. Icatlo, K. Umeda and Y. Kodama (2013): Oral passive IgY-based immunotherapeutics: A novel solution for prevention and treatment of alimentary tract diseases. Hum. Vacc. Immunother., 9, 1-10.

Reed, L. J. and H. Muench (1938): A simple method of estimating fifty percent end points. Am. J. Hyg., 27, 493-497.

Ronen, A., A. Perelberg, J. Abramowitz, M. Hutoran, S. Tinman, I. Bejerano, M. Steinitz and M. Kotler (2003): Efficient vaccine against the virus causing a lethal disease in cultured Cyprinus carpio. Vaccine, 21, 4677-4684.

Schade, R., I. Behn, M. Erhard and A. Hlinak (2001): Isolation of IgY from Yolk. In: Chicken Egg Yolk Antibodies, Production and Application IgY-Technology (ed. C. Staak.). springer-verlag Berlin Heidelberg New York, Germany, pp. 73-76.

St-Hilaire, S., N. Beevers, C. Joiner, R. P. Hedrick and K. Way (2009): Antibody response of two populations of common carp, Cyprinus carpio L., exposed to koi herpesvirus. J. Fish Dis., 32, 311-320.

Syakuri, H., M. Adamek, G. Brogden, K. Ł. Rakus, M. Matras, I. Irnazarow and D. Steinhagen (2013): Intestinal barrier of carp (Cyprinus carpio L.) during a cyprinid herpesvirus 3infection: Molecular identification and regulation of the mRNA expression of claudin encoding genes. Fish Shellfish Immunol., 34, 305-314.

Trkola, A., A. B. Pomales, H. Yuan, B. Korber, P. J. Maddon, G. P. Allaway, H. Katinger, C. F. Barbas 3rd, D. R. Burton, D. D. Ho and J. P. Moore (1995): Cross-Clade Neutralization of Primary Isolates of Human Immunodeficiency Virus Type 1 by Human Monoclonal Antibodies and Tetrameric CD4-IgG. J. Virol., 69, 6609-6617.

Weisburg, W. G., S. M. Barns, D. A. Pelletier and D. J. Lane (1991): 16S ribosomal DNA amplification for phylogenetic study. J. Bacteriol., 173, 697-703.

Yasumoto, S., Y. Kuzuya, M. Yasuda, T. Yoshimura and T. Miyazaki (2006): Oral immunization of common carp with a liposome vaccine fusing koi herpesvirus antigen. Fish Pathol., 41, 141-145. 